\title{
Sustainability Assessment for Wastewater Treatment Systems-Case Studies in Egypt
}

\author{
Yousra M. Zakaria', Ahmed El Gendy ${ }^{1}$, Salah El Haggar ${ }^{2}$ \\ ${ }^{1}$ Construction Engineering Department, The American University in Cairo, Cairo, Egypt \\ ${ }^{2}$ Mechanical Engineering Department, The American University in Cairo, Cairo, Egypt \\ Email: Yousra_m@aucegypt.edu, ahmed.elgendy@aucegypt.edu, elhaggar@aucegypt.edu
}

How to cite this paper: Zakaria, Y.M., El Gendy, A. and El Haggar, S. (2021) Sustainability Assessment for Wastewater Treatment Systems-Case Studies in Egypt. Journal of Environmental Protection, 12, 90-105.

https://doi.org/10.4236/jep.2021.122007

Received: January 8, 2021

Accepted: February 20, 2021

Published: February 23, 2021

Copyright $\odot 2021$ by author(s) and Scientific Research Publishing Inc. This work is licensed under the Creative Commons Attribution International License (CC BY 4.0).

http://creativecommons.org/licenses/by/4.0/

\begin{abstract}
Low sanitation coverage is a significant problem in Egypt, especially in rural areas. The Rapid Sustainability Screening (RSS) model was developed to assess the sustainability of wastewater treatment systems (WWTS), both planned and existing, and support decision-makers in selecting alternatives. The model considers the three fundamental sustainability dimensions, namely, environmental, social, and economic. In the present paper, the model was successfully tested by evaluating the sustainability performance of three operating rural WWTS in Egypt (Constructed Wetland (CW)-BeniSuef, Constructed Wetland (CW)-Dakahlia, and Activated Sludge (AS)-Gharbia). CW-BeniSuef was the most sustainable system based upon environmental and social considerations with values of 2.50 and 2.71 , respectively. On the other hand, CWDakahlia is the most economically sustainable system, with a value of 2.25. The highest sustainability overall ranking system was CW-BeniSuef with overall sustainability of 2.81 , followed by CW-Dakahlia with a value of 2.18 , and the least sustainable technology is AS-Gharbia (1.72). The RSS model can support the decision-makers and operators during the different phases of a wastewater treatment project development (e.g., feasibility, operation). The model has been developed in a user-friendly and straightforward manner. The simplicity of the model may encourage the decision-makers and EIA practitioners to expand the assessment to consider sustainability rather than focusing on one or two aspects only (i.e., environment and society) in isolation of the possible interaction between them.
\end{abstract}

\section{Keywords}

Sustainability Assessment, Rapid Sustainability Screening,

Rural Sanitation 


\section{Introduction}

Appropriate sanitation is generally linked with the health and wellbeing of communities. Diseases such as typhoid, cholera, and hepatitis A are strongly associated with poor sanitation [1] [2] [3]. The World Health Organization (WHO) statistics indicated that more than 400,000 annual deaths in low- and middleincome countries are attributed to inadequate sanitation [4]. Recognizing this global challenge's seriousness, one of the United Nations Sustainable Development Goals (SDGs) released in 2015 is to ensure access to water and sanitation for all [2]. Some targets are established to measures the progress of achieving this goal. Of relevance are Targets 6.2: end open defecation and provide access to sanitation and hygiene, Target 6.3: Improve water quality, wastewater treatment, and safe reuse; Target 6.A: Expand water and sanitation support to developing countries, and Target 6.B: Support local engagement in water and sanitation management [5].

Egypt, a lower-middle-income country, is characterized by low sanitation coverage in general and particularly low in rural communities. More than $57 \%$ of the Egyptian population (approximately 54,771,000 persons) are in rural areas, where $24.2 \%$ only of the buildings are connected to public sewer systems [6]. Different small-scale and customized wastewater treatment systems (WWTS) have been investigated and funded by international donors such as World Bank, USAID, and GIZ in response to the rural sanitation problem in Egypt [7] and [8].

A funded research project by the Swiss State Secretariat for Economic Affairs (SECO), titled the Egyptian-Swiss Research on Innovations in Sustainable Sanitation (ESRISS), focuses on rural sanitation in the Nile Delta. As part of this research, the Factsheets on Small-Scale Sanitation Initiatives in Egypt (hereafter, the ESRISS Factsheets) was published in December 2013 [9]. These ESRISS Factsheets presented information available on selected small-scale WWTS in Egypt. The data were collected through field visits and interviews with different stakeholders (e.g., designers).

It should be noted that very few practical sustainability assessments have been conducted worldwide in the field of WWTS [10] [11] [12] [13] [14]. Furthermore, to date, there exist no records of similar research work in Egypt. Consequently, there is a significant need in Egypt to develop a model that considers the globally-recognized sustainability dimensions and can also be tailored for local conditions.

The current work's key objective is to establish a tool, namely the Rapid Sustainability Screening (RSS) model, to assist decision-makers in selecting technology for WWTS in small communities or evaluating existing systems for improving their performance/sustainability. The objectives also include the verification/validation of this model by applying it to real case studies for existing wastewater treatment plants in Egypt's rural areas. The model verification/validation was carried out for three WWTS documented in the previously mentioned ESRISS Factsheets [9]. 
Egypt is currently expanding sanitation infrastructure with several projects to cover rural areas as part of the Country's ambitious 2030 Vision launched in 2016 [15]. One of the Key Performance Indicators for Environment until 2030 is to extend the sanitation coverage to reach $80 \%$ and achieve $100 \%$ compliance with the national standards for all the discharges to the Nile River.

As many technologies can be used for wastewater treatment, decision-makers need an evaluation tool that can be used to compare and select the most appropriate and sustainable technology for each unique scenario. Such a tool is essential as a screening step that can consider the local conditions and the socio-economic factors of the project area. This tool can also help in evaluating existing treatment plants to determine their overall sustainability.

The following sections of the present paper are structured as follows:

- Section 2: presents the methodology to be used in the assessment and definition of the factors to be studied.

- Section 3: presents an overview of the investigated systems (e.g., location, main components).

- Section 4: presents the sustainability assessment results (environmental/technical, economic, social, and overall).

- Section 5: presents the conclusion based on the findings of Section 4.

\section{Methodology of the Sustainability Screening Tool}

RSS is mainly based on the sustainability screening tool developed by the authors [16]. The typical sustainability aspects were studied as part of the RSS with the below-indicated weights:

- Economic: $40 \%$.

- Environmental/Technical: 30\%.

- Social: $30 \%$.

The above aspects are considered to be the typical/primary pillars of sustainability [17] [18] [19]. Typically, wastewater treatment technologies selection is mainly driven by financial considerations [13]. Also, Egypt is a developing country, and based on the authors' local experience; the economic aspects are typically the dominant decision-making factor; therefore, it has a higher weight criterion. Factors to be studied are grouped under the main sustainability aspects: environmental/technical, social, and economical.

A semi-quantitative approach was followed for the sustainability assessment. In this approach, a scale of 1 to 3 was used where one stands for low sustainability case (L), two is for the medium sustainability case $(\mathrm{M})$, and three is for high sustainability case $(\mathrm{H})$.

The following definitions were given for each of the previously mentioned rankings:

- Low (L): An alternative that violates one or more of the sustainability assessment considered factors regulated by the local law and/or does not meet the sustainability studied factors' overall requirements. 
- Medium (M): An alternative that just meets the overall requirements of the sustainability studied factors.

- High (H): An alternative that exceeds the overall requirements of the sustainability studied factors.

If the investigated treatment technology is associated with any violation of the local laws and regulations (e.g., inappropriate disposal of generated wastes or non-compliant discharge in terms of quality). In this case, it will be classified as Unsustainable, regardless of the possible ranking of the different aspects.

In addition, this assessment will apply only to systems that follow the design requirements if already in operation. In case the investigated system is at the design stage/pre-implementation phase, it will be assumed that the system will be operated following the design. More details on the different factors covered by each of the sustainability aspects are presented below. Tables 1-3 show the proposed ranking for each environmental/technical, economic, and social factors. The factors are of equal weight, as shown in the equation below:

$$
\begin{aligned}
& \text { Overall Sustainability Index }=0.30 \times[\underbrace{\left[\frac{\text { Factor } 1+\text { Factor } 2+\cdots+\text { Factor } 6}{6}\right]}_{\text {Environmental/Technical Aspect }} \\
& +0.4 \times \underbrace{\left[\frac{\text { Factor } 1+\text { Factor } 2+\text { Factor } 3+\text { Factor } 4}{4}\right]}_{\text {Economic Aspect }} \\
& +0.30 \times \underbrace{\left[\frac{\text { Factor } 1+\text { Factor } 2+\cdots+\text { Factor } 7}{7}\right]}_{\text {Social Aspect }}
\end{aligned}
$$

\begin{tabular}{|c|c|c|c|c|}
\hline$\#$ & Factor & Condition & Rank & $\begin{array}{c}\text { Corresponding } \\
\text { value }\end{array}$ \\
\hline \multirow{3}{*}{1} & \multirow{3}{*}{$\begin{array}{l}\text { The removal efficiency of } \\
\text { pollutants from wastewater }\end{array}$} & Not meeting local limits & $\mathrm{L}$ & 1 \\
\hline & & Meeting the local limits & M & 2 \\
\hline & & Below the local limits & $\mathrm{H}$ & 3 \\
\hline \multirow{3}{*}{2} & \multirow{3}{*}{$\begin{array}{l}\text { Energy used/generated in the } \\
\text { treatment processes }\end{array}$} & $\begin{array}{l}\text { Extensive energy consumption } \\
\left(>1.122 \mathrm{kWh} / \mathrm{m}^{3}\right)\end{array}$ & $\mathrm{L}$ & 1 \\
\hline & & $\begin{array}{l}\text { Moderate energy consumption } \\
\left(0.38-1.122 \mathrm{kWh} / \mathrm{m}^{3}\right)\end{array}$ & M & 2 \\
\hline & & $\begin{array}{l}\text { Passive system or } \\
\text { energy-producing system }\end{array}$ & $\mathrm{H}$ & 3 \\
\hline \multirow{3}{*}{3} & \multirow{3}{*}{ Sludge quality for useful utilization } & $\begin{array}{l}\text { Low-quality sludge containing } \\
\text { pollutants (heavy metals, toxic } \\
\text { substances) }\end{array}$ & $\mathrm{L}$ & 1 \\
\hline & & $\begin{array}{l}\text { Sludge suitable for composting } \\
\text { and/or landscape with } \\
\text { complete treatment processes }\end{array}$ & M & 2 \\
\hline & & $\begin{array}{l}\text { Sludge suitable for composting } \\
\text { and/or landscape with simple } \\
\text { treatment processes that do } \\
\text { not require skilled labor }\end{array}$ & $\mathrm{H}$ & 3 \\
\hline
\end{tabular}

Table 1. Assessment ranking for environmental/technical factors. 


\section{Continued}

4 Reliability $^{\mathrm{b}}$

Odor/gaseous emissions
Technology is sensitive to

changes in the influent

operating conditions (e.g.,

toxic matter, shock loads, etc.)

L

1

The impact of the changes is

irreversible

Technology is sensitive to

changes in the influent

operating conditions (e.g.,

toxic matter, shock loads, etc.);

M

however, the changes' impact

is reversible.

Technology is independent

of the influent operating

$\mathrm{H} \quad 3$

conditions.

Odor outside the facility

boundaries

L 1

Odor inside the facility

boundaries, only

M 2

No odor outside the facility

boundaries

$\mathrm{H} \quad 3$

Complex system and/or

Not-well established

technology

6 Complexity
Moderately complex technology and/or well established

Simple technology
L $\quad 1$

M 2

$\mathrm{H} \quad 3$

${ }^{a}$ These values are only for guidance [20]; ${ }^{b}$ There is no unified definition of wastewater treatment plants reliability [21], and thus the authors developed the above definitions for this methodology.

Table 2. Assessment ranking for economic factors.

\begin{tabular}{|c|c|c|c|c|}
\hline$\#$ & Factor & Condition & Rank & $\begin{array}{l}\text { Corresponding } \\
\text { value }\end{array}$ \\
\hline \multirow{3}{*}{1} & \multirow{3}{*}{ Construction $\operatorname{cost}^{\mathrm{C}}$} & $\begin{array}{l}\text { High construction cost }(>700 \\
\left.\mathrm{USD} / \mathrm{m}^{3} / \mathrm{d}\right)\end{array}$ & $\mathrm{L}$ & 1 \\
\hline & & $\begin{array}{l}\text { Moderate construction cost } \\
\left(700-400 \mathrm{USD} / \mathrm{m}^{3} / \mathrm{d}\right)\end{array}$ & M & 2 \\
\hline & & $\begin{array}{l}\text { Low construction cost }(<400 \\
\left.\mathrm{USD} / \mathrm{m}^{3} / \mathrm{d}\right)\end{array}$ & $\mathrm{H}$ & 3 \\
\hline \multirow{3}{*}{2} & \multirow{3}{*}{$\begin{array}{l}\text { Operation and maintenance } \\
\text { costs }^{\mathrm{C}}\end{array}$} & High cost $\left(>3 \mathrm{USD} / \mathrm{m}^{3} / \mathrm{d}\right)$ & $\mathrm{L}$ & 1 \\
\hline & & $\begin{array}{l}\text { Moderate cost }(3-0.5 \\
\left.\mathrm{USD} / \mathrm{m}^{3} / \mathrm{d}\right)\end{array}$ & M & 2 \\
\hline & & Low cost $\left(<0.5 \mathrm{USD} / \mathrm{m}^{3} / \mathrm{d}\right)$ & $\mathrm{H}$ & 3 \\
\hline \multirow{3}{*}{3} & \multirow{3}{*}{$\begin{array}{l}\text { Cost of the required area of } \\
\text { land }\end{array}$} & High cost & $\mathrm{L}$ & 1 \\
\hline & & Moderate cost & M & 2 \\
\hline & & Low cost & $\mathrm{H}$ & 3 \\
\hline
\end{tabular}




\section{Continued}

\begin{tabular}{|c|c|c|c|c|}
\hline \multirow{3}{*}{4} & \multirow{3}{*}{$\begin{array}{l}\text { Possibility of producing } \\
\text { valuable products for the } \\
\text { local community }\end{array}$} & $\begin{array}{l}\text { No economically feasible } \\
\text { products are produced }\end{array}$ & $\mathrm{L}$ & 1 \\
\hline & & $\begin{array}{l}\text { Economically feasible products } \\
\text { are produced; however, of low } \\
\text { economic benefit to the local } \\
\text { community }\end{array}$ & $\mathrm{M}$ & 2 \\
\hline & & $\begin{array}{l}\text { Economically feasible products } \\
\text { are produced; and of high } \\
\text { economic benefit to the local } \\
\text { community (e.g., compost) }\end{array}$ & $\mathrm{H}$ & 3 \\
\hline
\end{tabular}

aIt should be noted that the definition given for the high, moderate and low costs are mainly based on values reported by El Nadi [22] and are corrected based on the average inflation rates in Egypt. These values are only for guidance and tailored for the Egyptian conditions. Should this model be used in other countries, the assessor(s) should determine the acceptable definitions based on their prevailing local conditions. In general, operation and maintenance costs account for operation team salaries, routine maintenance, spare parts replacement costs, etc.

Table 3. Assessment ranking for social factors.

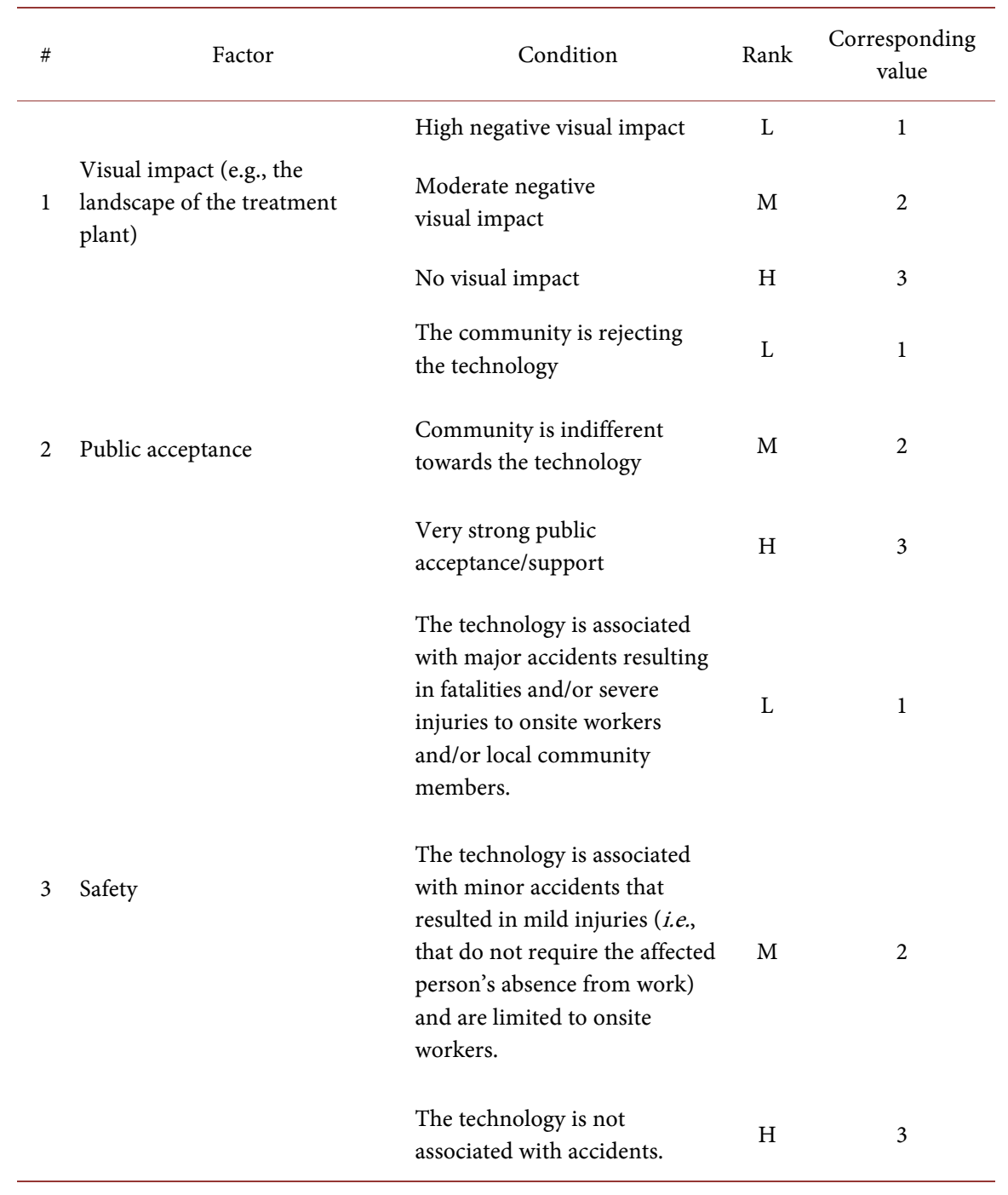




\begin{tabular}{|c|c|c|c|c|}
\hline \multicolumn{5}{|c|}{ Continued } \\
\hline \multirow{3}{*}{4} & \multirow{3}{*}{ Noise } & $\begin{array}{l}\text { Noise levels are high and } \\
\text { extend beyond the plant } \\
\text { boundaries }\end{array}$ & $\mathrm{L}$ & 1 \\
\hline & & $\begin{array}{l}\text { Noise is limited to treatment } \\
\text { plant boundaries }\end{array}$ & M & 2 \\
\hline & & No noise & $\mathrm{H}$ & 3 \\
\hline \multirow{2}{*}{5} & Job opportunities for & No & $\mathrm{L}$ & 1 \\
\hline & local residents & Yes & $\mathrm{H}$ & 3 \\
\hline \multirow[t]{2}{*}{6} & $\begin{array}{l}\text { Need for international/ } \\
\text { non-local experts for }\end{array}$ & Yes & $\mathrm{L}$ & 1 \\
\hline & design/maintenance/operation & No & $\mathrm{H}$ & 3 \\
\hline \multirow{3}{*}{7} & Surn & $\begin{array}{l}\text { A very high decrease in land } \\
\text { value }(>50 \%)\end{array}$ & $\mathrm{L}$ & 1 \\
\hline & $\begin{array}{l}\text { decrease due to the presence } \\
\text { of the treatment plant }\end{array}$ & $\begin{array}{l}\text { A minor decrease in land value } \\
(<50 \%)\end{array}$ & M & 2 \\
\hline & & No land value decrease & $\mathrm{H}$ & 3 \\
\hline
\end{tabular}

Suppose one or more pollutants is not meeting the legal limit. In that case, the alternative's overall ranking shall be classified as Unsustainable as the applicable local laws generally regulate the treated effluent quality. It should be noted that Egypt has different standards depending on the final disposal of the treated effluent (e.g., discharge to the marine environment, reuse in irrigation).

\section{Case Studies Overview}

The systems investigated are Activated Sludge (AS) in Gharbia governorate, Constructed Wetland (CW) in BeniSuef governorate and Constructed Wetland (CW) in Dakahlia governorate (Figure 1).

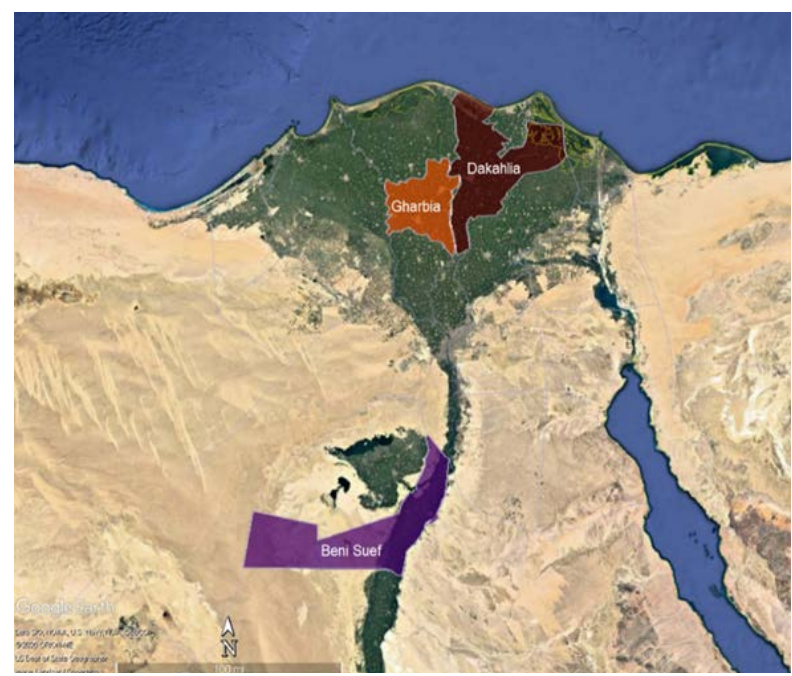

Figure 1. Location of Gharbia, Beni Suef, and Dakahlia governorates. 
Table 4. Basic information [9].

\begin{tabular}{|c|c|c|c|c|c|c|c|}
\hline$\#$ & Treatment-Location & Coverage & $\begin{array}{l}\text { Operation } \\
\text { Start Date }\end{array}$ & Additional Information & & System component & \\
\hline 1 & $\begin{array}{l}\text { Activated Sludge } \\
\text { (AS)-Gharbia }\end{array}$ & $\begin{array}{c}6000 \\
\text { inhabitants }\end{array}$ & 2010 & $\begin{array}{l}\text { Typical activated sludge wastewater } \\
\text { treatment facility. }\end{array}$ & Influent & clanfler & $\underset{\text { Effluent, }}{\longrightarrow}$ \\
\hline 2 & $\begin{array}{l}\text { Constructed Wetland } \\
\text { (CW)-BeniSuef }\end{array}$ & $\begin{array}{l}\text { 10,000 inha- } \\
\text { bitants }^{\mathrm{d}}\end{array}$ & 2009 & $\begin{array}{l}\text { It consists of the following units: } \\
\text { three primary settling tanks in } \\
\text { parallel, aeration unit, sub-flow } \\
\text { constructed wetland, oxidation } \\
\text { channel, and sludge treatment unit } \\
\text { (drying beds). }\end{array}$ & & & Ethourent \\
\hline 3 & $\begin{array}{l}\text { Constructed Wetland } \\
\text { (CW)-Dakahlia }\end{array}$ & $\begin{array}{c}6500 \\
\text { inhabitants }\end{array}$ & 1999 & $\begin{array}{l}\text { It consists of the following units: } \\
\text { sub-flow constructed wetlands } \\
\text { (two stages) and oxidation pond. }\end{array}$ & $\stackrel{\text { Influent }}{\longrightarrow}$ & & Effluent \\
\hline
\end{tabular}

bource: Together association for development and environment website, accessed in August 2020.

The assessment is based on the available information in the ESRISS Factsheets [9] and the authors' experience designing and monitoring the performance of similar wastewater treatment plants in rural communities in Egypt.

The three existing systems were selected as case studies to investigate the validity and applicability of the tool. For accurate comparison of the results, the three systems were chosen to be of similar size/population.

Table 4 shows the basic information for the investigated case studies. As shown in the table, the three selected systems represent the commonly used conventional systems in Egypt, especially in rural areas.

\section{Sustainability Assessment}

\subsection{Environmental/Technical Sustainability}

None of the three investigated systems reported a non-compliance problem with the regulating limits of treated effluent quality in Egypt concerning safe final disposal. Consequently, they cannot be classified as Low. However, although not explicitly quantified in terms of removal efficiency percentage, it could be noted that the treated effluent quality varied among the systems. High removal efficiencies were reported for CW-Dakahlia and AS-Gharbia. It was indicated that the treated effluent for CW-Dakahlia meets the requirements for reuse in irrigation, while the quality of the AS-Gharbia was described as very good. Consequently, the pollutants removal efficiencies for both systems were ranked as Medium.

No information was provided for treated effluent quality from CW-BeniSuef; however, various research papers indicated that $\mathrm{CW}$ is generally an efficient treatment technology [23] [24] [25] [26] and thus, can be conservatively classified as Medium.

Regarding energy, the ranking varied among the systems as per the provided data in the ESRISS Factsheets [9]. CW-Dakahlia and CW-BeniSuef were ranked 
as Medium. CW-Dakahlia and CW-BeniSuef's treatment plants include aeration as part of the treatment process, which requires additional power. On the other hand, AS-Gharbia power requirements are high and consequently ranked as Low. These remarks are consistent with the literature of various researchers. For example, several research papers indicate that CWs are characterized by low energy consumption [27] [28] [29]; unlike AS, which is typically associated with high energy demands [29] [30] [31].

The sludge was reported to have good quality for two of the systems. ASGharbia and CW-BeniSuef produce high-quality sludge utilized by the local community and thus classified as High. As for CW-Dakahlia, the sludge's quality was not presented in the ESRISS Factsheets [9]; however, it cannot be classified as Low due to the absence of toxic matter/heavy metals sources in the influent of the treatment facility and consequently the resulting sludge. Following a conservative approach, it can be categorized as Medium.

The odors associated with CW and AS systems are localized and not significant, especially if adequately designed [32] and [33]. Thus, the odor factor is classified as High for each of the analyzed systems.

There are no records on the different tested systems' reliability status/potential in the ESRISS Factsheets [9]. Some early research work conducted to assess CW reliability indicated that this system has low reliability [34] and [35]; however, more recent research [36] demonstrated that CW is a reliable wastewater treatment system. Following a conservative approach, both CW-BeniSuef and CW-Dakahlia are classified as Medium.

As for AS, it is generally considered to be more reliable than other systems such as ponds [37]. However, it depends on the influent's characteristics [38] and cannot be classified as High. Consequently, AS-Gharbia is categorized as Medium.

As for complexity, constructed wetlands are generally classified as easy to operate technology [27]. As a result, CW-BeniSuef can be classified as High. However, CW-Dakahlia is classified as Low as technical difficulties have been reported during the operations [9]. AS is generally a well-established technology worldwide [39]; however, it is considered more complex than CW. Consequently, AS-Gharbia can be classified as Medium.

CW-BeniSuef has environmental sustainability of 2.50, followed by AS-Gharbia with a value of 2.17 and then CW-Dakahlia with a value of 2.00 .

\subsection{Economic Sustainability}

AS-Gharbia is serving a population of 6000 [9], which corresponds to a capacity of about $1020 \mathrm{~m}^{3} /$ day (assuming an average per capita wastewater generation of $170 \mathrm{l} /$ day). Given that the treatment plant's construction cost is 18 million EGP [9] and the USD average exchange rate in 2010 (the year when the plant was built) is 5.65 , the approximate construction cost of the plant is 3123 USD/ $\mathrm{m}^{3} / \mathrm{d}$. Consequently, this alternative is classified as Low in terms of construction cost. A similar remark is made for CW-BeniSuef, as the approximate construc- 
tion cost is about $772 \mathrm{USD} / \mathrm{m}^{3} / \mathrm{d}$ given the reported construction cost (1.2 million EGP), actual capacity $\left(300 \mathrm{~m}^{3} / \mathrm{d}\right)$, and USD average exchange rate in 2009 when the plant was built (5.54). On the other hand, CW-Dakahlia is classified as Medium in terms of construction cost (approximately $551 \mathrm{USD} / \mathrm{m}^{3} / \mathrm{d}$ ). This ranking is given the reported construction cost of 2.25 million EGP, the capacity of 1200 $\mathrm{m}^{3} / \mathrm{d}$, and the USD average exchange rate of 3.4 in 1999 (when the plant was built).

Based on the operation and maintenance costs reported in ESRISS Factsheets [9], AS-Gharbia has the highest cost $\left(5 \mathrm{USD} / \mathrm{m}^{3} / \mathrm{d}\right)$ and thus classified as Low, followed by CW-BeniSuef ( $1 \mathrm{USD} / \mathrm{m}^{3} / \mathrm{d}$ ), which can be classified as Medium. The lowest cost was reported for CW-Dakahlia $\left(0.27 \mathrm{USD} / \mathrm{m}^{3} / \mathrm{d}\right)$, and it is classified as High.

The required land area cost is typically directly proportional to the area required. The ESRISS Factsheets [9] does not specify the area of land needed for each investigated system. Thus, the following assessment of the required land area cost factor is based on the available literature and the authors' experience.

CW is typically associated with the high area required for treatment and the highest land cost, whereas much less area is required for activated sludge [22]. As a result, the cost of the area needed for both CW-Dakahlia and CW-BeniSuef are classified as Low. For AS-Gharbia, this factor is classified as Medium.

This last factor creates the potential for valuable byproducts, which could raise the classification for CW-Dakahlia to High. The Dakahlia wetland produces papyrus that is a potential source of income [9]. A similar remark was reported for AS-Gharbia, as the produced sludge is processed to make compost, which is typically a valuable product in agricultural areas. Nonetheless, the lack of appropriate marketing resulted in low revenue [9], so AS-Gharbia can only be classified as Medium. On the other hand, there is no mention of similar valuable products for CW-BeniSuef, and it is classified as Low.

The highest economic sustainability is reported for CW-Dakahlia (2.25), followed by AS-Gharbia (1.50), and the least economic sustainability is reported for CW-BeniSuef (1.25).

\subsection{Social Sustainability}

The ESRISS Factsheets [9] does not address the visual impact for each of the investigated systems. Thus, the following assessment of the visual impact factor is based on the available literature and the authors' experience. CWs are characterized by their limited visual impact compared with other treatment facilities [28] and [40]. Consequently, both CW-BeniSuef and CW-Dakahlia are classified as High; whereas, AS-Gharbia is classified as Medium following a conservative approach assuming that it has a higher visual impact than CW.

The ESRISS Factsheets [9] showed that the community runs CW-BeniSuef, and there is a well-established relationship with the NGO which initiated the treatment plant implementation. Consequently, the public acceptance factor has been classified as High for CW-BeniSuef. On the other hand, the local commu- 
nity was not interested in operating the AS-Gharbia; furthermore, the ESRISS documented a conflict between the plant operator and the local community [9]. As a result, the public acceptance for AS-Gharbia has been categorized as Low.

There is no available information on the local community's attitude towards CW-Dakahlia in the ESRISS. However, there are no records of grievances from the local community. Furthermore, the public reports indicate that rural communities in Egypt generally support the establishment of wastewater treatment plants to improve the overall quality of living in their community. They also reduce the potential for diseases [41] [42] [43]. A such, the public acceptance factor can be classified as Medium following a conservative approach.

As for noise, the ESRISS Factsheets [9] did not address this issue. However, $\mathrm{CW}$ is characterized by no noise emissions in general; on the contrary, it can contribute to noise reduction [44]. Consequently, both CW-Dakahlia and CWBeniSuef are classified as High. Noise is expected in activated sludge treatment plants, mainly due to the aeration process [28], and thus AS-Gharbia can be classified as Medium.

As for local residents' job opportunities, it was stated that CW-BeniSuef technical support is provided by a local NGO and thus classified as High. There is no available information reported on the CW-Dakahlia labor force and whether they are locals or not; however, given the fact that the system is easy to operate, it can be assumed that local residents in the nearby village might be able to provide the necessary support to the system and thus it was classified as High. On the contrary, for AS-Gharbia, it was stated in the ESRISS Factsheets [9] that the local residents decided not to operate the plant, and thus it has been classified as Low.

Regarding the need for international/non-local experts, as stated in the ESRISS Factsheets [9], AS-Gharbia is operated by an electrical engineer (i.e., skilled labor) is not typically present in an Egyptian rural community), it can be classified as Low. On the other hand, CW-BeniSuef is characterized by dependence on the local community [9], and thus it can be classified as High. CWDakahlia was first designed and developed by international experts [9]; furthermore, it was then rehabilitated by Egyptian experts (i.e., not from the local rural community) and classified as Low.

As for safety, no records for incidents or near-misses were stated in the ESRISS Factsheets [9]; however, following a conservative approach, the different systems will classify each system as Medium. A similar approach is followed for land value decrease assessment. There are no records on this factor; however, a conservative approach is followed, and the different systems can be classified as Medium.

The highest social sustainability is reported for CW-BeniSuef (2.71), followed by CW-Dakahlia (2.29), and the least social sustainability is reported for ASGharbia (1.57).

\subsection{Overall Sustainability}

As shown in Figure 2, some systems showed a higher overall sustainability 


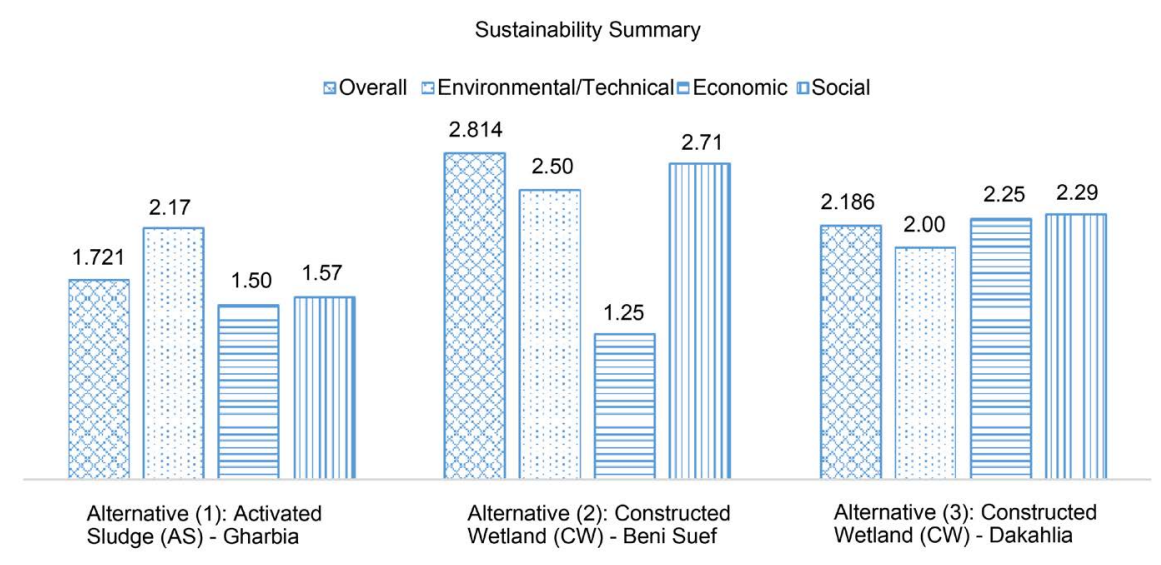

Figure 2. Overall sustainability results.

ranking than others. The most sustainable technology among the different systems investigated in this paper is CW-BeniSuef, with overall sustainability of 2.81 , followed by CW-Dakahlia with a value of 2.18 , and the least sustainable technology is AS-Gharbia (1.72).

\section{Conclusions}

The RSS model has proven its applicability to existing wastewater treatment systems in Egypt. The findings indicated that simple systems supported/operated by local communities (such as constructed wetlands) showed higher sustainability than sophisticated well-established systems (such as activated sludge) in rural communities. The low sustainability ranking for AS-Gharbia is consistent with the ESRISS Factsheets [9] findings, which indicated that AS is not a suitable technology for small communities. The model should be examined for the case of existing/operating wastewater treatment facilities to identify their sustainability potentials and identify weak points that hinder their sustainable operations for further improvement.

Furthermore, it can be used during the planning phase and alternative selections as well. This model can represent a valuable addition to the typical environmental impact assessment approach for licensing new projects. In Egypt and similar to many countries around the world, an Environmental Impact Assessment (EIA)/Environmental and Social Impact Assessment (ESIA) study is required by the regulator for project licensing [45]. The authors managed to develop and successfully test a semi-quantitative assessment tool that is simple and user-friendly. The tool's simplicity was deliberately done to encourage the decision-makers and EIA practitioners to expand the assessment of new WWTPs to consider sustainability rather than focusing on one or two aspects only (i.e., environment and/or society) in isolation of the possible interaction between them.

The RSS tool can be potentially applied to WWTPs in other countries as the assessment factors are not local conditions dependent and generic. However, minor modifications to account for the relevant local conditions (e.g., construction cost proposed guidance values for Low, Medium, and High sustainability) 
will be required by the local assessors.

The majority of rural communities in Egypt are generally deprived of the appropriate sanitation services. The three sustainability dimensions can support the proper selection of a wastewater treatment system for a given community. The present paper findings indicated that simple systems supported/operated by local communities such as constructed wetlands showed higher sustainability than sophisticated well-established systems such as activated sludge in rural communities. However, further investigation is required to more accurately assess some of the factors, such as land value decrease, that have been ranked in the present paper based on the experience of the authors rather than factual field data.

\section{Conflicts of Interest}

The authors declare no conflicts of interest regarding the publication of this paper.

\section{References}

[1] Marzouk, M. and Othman, A. (2017) Modeling the Performance of Sustainable Sanitation Systems Using Building Information Modeling. Journal of Cleaner Production, 141, 1400-1410. https://doi.org/10.1016/j.jclepro.2016.09.226

[2] Munamati, M., Nhapib, I. and Misia, S. (2016) Exploring the Determinants of Sanitation Success in Sub-Saharan Africa. Water Research, 103, 435-443. https://doi.org/10.1016/j.watres.2016.07.030

[3] Mara, D. (2004) Domestic Wastewater Treatment in Developing Countries. Earthscan Publications, London.

[4] World Health Organization (2020) Sanitation. https://www.who.int/news-room/fact-sheets/detail/sanitation

[5] Ritchie, R. and Mispy, O.-O. (2018) Measuring Progress towards the Sustainable Development Goals.

[6] Central Agency for Public Mobilization and Statistics, Statistical Yearbook 2019, Ref No. 71-01111-2019.

[7] USAID, Water and Sanitation.

[8] MOIC, Program for Results Information Document, Concept Stage.

[9] Reymond, P. (2013) ESRISS Factsheets on Small-Scale Sanitation Initiatives in Egypt, Eawag, Seco, HCWW, Cairo.

[10] Padilla-Rivera, A. and Patricia Güereca, L. (2019) A Proposal Metric for Sustainability Evaluations of Wastewater Treatment Systems (SEWATS). Ecological Indicators, 103, 22-33. https://doi.org/10.1016/j.ecolind.2019.03.049

[11] Mahjouri, M., Bakri Ishak, M., Torabian, A., Abd Manaf, L. and Halimoon, N. (2017) The Application of a Hybrid Model for Identifying and Ranking Indicators for Assessing the Sustainability of Wastewater Treatment Systems. Sustainable Production and Consumption, 10, 21-37. https://doi.org/10.1016/j.spc.2016.09.006

[12] Diaz-Elsayed, N., Xu, X., Balaguer-Barbosa, M. and Zhang, Q. (2017) An Evaluation of the Sustainability of Onsite Wastewater Treatment Systems for Nutrient Management. Water Research, 121, 186-196.

https://doi.org/10.1016/j.watres.2017.05.005 
[13] Molinos-Senante, M., Gómez, T., Garrido-Baserba, M., Caballero, R. and Sala-Garrido, R. (2014) Assessing the Sustainability of Small Wastewater Treatment Systems: A Composite Indicator Approach. Science of the Total Environment, 497-498, 607617. https://doi.org/10.1016/j.scitotenv.2014.08.026

[14] Balkema, A.J., Preisig, H.A., Otterpohl, R. and Lambert, F.J.D. (2002) Indicators for the Sustainability Assessment of Wastewater Treatment Systems. Urban Water, 4, 153-161. https://doi.org/10.1016/S1462-0758(02)00014-6

[15] Ministry of Planning and Economic Development.

[16] Zakaria Ahmed, Y., El-Gendy, A. and El-Haggar, S. (2017) Sustainability Assessment of Municipal Wastewater Treatment. International Journal of Environmental, Chemical, Ecological, Geological and Geophysical Engineering, 11, 92-96.

[17] Saad, M.H., Nazzala, M.A. and Darras, B.M. (2019) A General Framework for Sustainability Assessment of Manufacturing Processes. Ecological Indicators, 97, 211-224. https://doi.org/10.1016/j.ecolind.2018.09.062

[18] Arodudu, O., Helming, K., Wiggering, H. and Voinov, A. (2017) Towards a More Holistic Sustainability Assessment Framework for Agro-Bioenergy Systems-A Review. Environmental Impact Assessment Review, 62, 61-75.

https://doi.org/10.1016/j.eiar.2016.07.008

[19] Huysegoms, L. and Cappuyns, V. (2017) Critical Review of Decision Support Tools for Sustainability Assessment of Site Remediation Options. Journal of Environmental Management, 196, 278-296. https://doi.org/10.1016/j.jenvman.2017.03.002

[20] BarrosoSoares, R., Santos Memelli, M., Pereira Roque, R. and Franci Gonçalves, R. (2017) Comparative Analysis of the Energy Consumption of Different Wastewater Treatment Plants. International Journal of Architecture, Arts and Applications, 3, 7986. https://doi.org/10.11648/j.ijaaa.20170306.11

[21] Piadeh, F., Ahmadi, M. and Behzadian, K. (2018) Reliability Assessment for Hybrid Systems of Advanced Treatment Units of Industrial Wastewater Reuse Using Combined Event Tree and Fuzzy Fault Tree Analyses. Journal of Cleaner Production, 201, 958-973. https://doi.org/10.1016/j.jclepro.2018.08.052

[22] El Nadi, M. (2005) Wastewater Treatment Design Report. Technical Report No. 8. LIFE Integrated Water Resources Management, Task Order No. 802.

[23] Xu, X., Mills, G., Lindell, A., Peck, E., Korotasz, A. and Burgess, E. (2019) The Performance of a Free Surface and Metal-Removing Constructed Wetland: How a Young Wetland Becomes Mature. Journal of Ecological Engineering, 133, 32-38. https://doi.org/10.1016/j.ecoleng.2019.04.020

[24] Chen, J., Liu, Y., Deng, W. and Ying, G. (2019) Removal of Steroid Hormones and Biocides from Rural Wastewater by an Integrated Constructed Wetland. Science of the Total Environment, 660, 358-365.

https://doi.org/10.1016/j.scitotenv.2019.01.049

[25] Sardana, A., Cottrell, B., Soulsby, D. and Aziz, T. (2019) Dissolved Organic Matter Processing and Photoreactivity in a Wastewater Treatment Constructed Wetland. Science of the Total Environment, 648, 923-934. https://doi.org/10.1016/j.scitotenv.2018.08.138

[26] Nandakumar, S., Pipil, H., Ray, S. and Haritash, A.K. (2019) Removal of Phosphorous and Nitrogen from Wastewater in Brachiaria-Based Constructed Wetland. Chemosphere, 233, 216-222. https://doi.org/10.1016/j.chemosphere.2019.05.240

[27] Wu, H., Zhang, J., Ngo, H., Guo, W. and Liang, S. (2017) Evaluating the Sustainability of Free Water Surface Flow Constructed Wetlands: Methane and Nitrous Oxide Emissions. Journal of Cleaner Production, 147, 152-156. 
https://doi.org/10.1016/j.jclepro.2017.01.091

[28] Machado, A., Beretta, M., Fragoso, R. and Duarte, E. (2017) Overview of the State of the Art of Constructed Wetlands for Decentralized Wastewater Management in Brazil. Journal of Environmental Management, 187, 560-570.

https://doi.org/10.1016/j.jenvman.2016.11.015

[29] Martínez-Alcalá, I., Guillén-Navarro, J. and FernándezLópez, C. (2017) Pharmaceutical Biological Degradation, Sorption and Mass Balance Determination in a Conventional Activated-Sludge Wastewater Treatment Plant from Murcia, Spain. Chemical Engineering Journal, 316, 332-340. https://doi.org/10.1016/j.cej.2017.01.048

[30] Flores, L., García, J., Pena, R. and Garfí, M. (2019) Constructed Wetlands for Winery Wastewater Treatment: A Comparative Life Cycle Assessment. Science of the Total Environment, 659, 1567-1576. https://doi.org/10.1016/j.scitotenv.2018.12.348

[31] Hossain, M., Paparini, A. and Cord-Ruwisch, R. (2017) Rapid Adaptation of Activated Sludge Bacteria into a Glycogen Accumulating Biofilm Enabling Anaerobic BOD Uptake. Bioresource Technology, 228, 1-8. https://doi.org/10.1016/j.biortech.2016.11.102

[32] Bhatla, M. (1975) Control of Odors at an Activated Sludge Plant. Journal of the Water Pollution Control Federation, 47, 281-290. http://www.jstor.org/stable/25038629

[33] EPA (2020) Manual Constructed Wetlands Treatment of Municipal Wastewaters.

[34] Jozwiakowski, K., Bugajski, P., Mucha, Z., Wójcik, W., Jucherski, A., Nastawny, M., Siwiec, T., Mazur, A., Obros'lak, R. and Gajewska, M. (2017) Reliability and Efficiency of Pollution Removal during Long-Term Operation of a One-Stage Constructed Wetland System with Horizontal Flow. Separation and Purification Technology, 187, 60-66. https://doi.org/10.1016/j.seppur.2017.06.043

[35] Jozwiakowskia, K., Bugajski, P., Kurek, K., de FátimaNunes de Carvalho, M., Adelaide Araújo Almeida, M., Siwiec, T., Borowskie, G., Czekała, W., Dach, J. and Gajewsk, M. (2018) The Efficiency and Technological Reliability of Biogenic Compounds Removal during Long-Term Operation of a One-Stage Subsurface Horizontal Flow Constructed Wetland. Separation and Purification Technology, 202, 216-226. https://doi.org/10.1016/j.seppur.2018.03.058

[36] Marzec, M., Gizińska-Górna, M., Jóźwiakowski, K., Pytka-Woszczyło, A., Kowalczyk-Juśko, A. and Gajewska, M. (2019) The Efficiency and Reliability of Pollutant Removal in a Hybrid Constructed Wetland with Giant Miscanthus and Jerusalem Artichoke in Poland. Journal of Ecological Engineering, 127, 23-35.

https://doi.org/10.1016/j.ecoleng.2018.11.008

[37] Oliveira, S. and Von Sperling, M. (2008) Reliability Analysis of Wastewater Treatment Plant. Water Research, 42, 1182-1194.

https://doi.org/10.1016/j.watres.2007.09.001

[38] Boonnorat, J., Techkarnjanaruk, S., Honda, R., Angthong, S., Boonapatcharoen, N., Muenmee, S. and Prachanurak, P. (2018) Use of Aged Sludge Bioaugmentation in Two-Stage Activated Sludge System to Enhance the Biodegradation of Toxic Organic Compounds in High Strength Wastewater. Chemosphere, 202, 208-217. https://doi.org/10.1016/j.chemosphere.2018.03.084

[39] Hreiz, R., Latifi, M.A. and Roch, N. (2015) Optimal Design and Operation of Activated Sludge Processes: State-of-the-Art. Chemical Engineering, 281, 900-920. https://doi.org/10.1016/j.cej.2015.06.125

[40] Matamoros, V., Rodriguez, Y. and Bayona, J. (2017) Mitigation of Emerging Contaminants by Full-Scale Horizontal Flow Constructed Wetlands Fed with Secondary 
Treated Wastewater. Ecological Engineering, 99, 222-227.

https://doi.org/10.1016/j.ecoleng.2016.11.054

[41] Al Dar in Association with CH2MHILL, Second Integrated Sanitation and Sewerage Infrastructure Project-ISSIP (II) Environmental and Social Assessment Framework, Executive Summary, January 2011.

[42] EcoConServ, Environmental and Social Impact Assessment for Rural Clusters under Phase 1 of ISSIP II Project-Assiut Governorate Updated ESIA Report, April 2017.

[43] EcoConServ, Environmental and Social Impact Assessment for Rural Clusters under Phase 1 of ISSIP II Project-Sohag Governorate Executive Summary, 2016.

[44] Moinier, S. (2013) Constructed Wetlands Redefined as Functional Wetlands. Deltares SO MT Kennis. Project 1202415.047.

[45] Egyptian Environmental Law, Law 4/1994 for the Protection of the Environment. 